\title{
IMMOBILIZATION OF SACCHAROMYCES CEREVISIAE IN NOVEL HYDROGELS BASED ON HYBRID NETWORKS OF POLY(ETHYLENE OXIDE), ALGINATE AND CHITOSAN FOR ETHANOL PRODUCTION
}

\author{
Ružica Jovanović-Malinovska ${ }^{1}$, Maja Cvetkovska ${ }^{2}$, Slobodanka Kuzmanova ${ }^{1}$, \\ Christo Tsvetanov ${ }^{3}$, Eleonora Winkelhausen ${ }^{1 *}$ \\ ${ }^{1}$ Department of Food Technology and Biotechnology, ${ }^{2}$ Department of Polymer Science, \\ Faculty of Technology and Metallurgy, Ss. Cyril and Methodius University, \\ Rudjer Bošković 16, 1000 Skopje, Republic of Macedonia \\ ${ }^{3}$ Institute of Polymers, Bulgarian Academy of Sciences, Bl. 103-A, \\ Acad. G. Bonchev Str. 1113, Sofia, Bulgaria \\ eleonora@tmf.ukim.edu.mk
}

Hydrogel matrices were designed as hybrid networks of poly(ethylene oxide) (PEO) with natural polymers, alginate or chitosan by UV irradiation. The networks were formulated in the single-stage procedure in which the alginate or chitosan were added to the crosslinking reaction solution of PEO, and two-stage procedure, with additional chemical crosslinking of alginate or chitosan. Double-layer hydrogels composed of PEO hydrogel core with entrapped cells and outer natural hydrogel layer were also synthesized. The hydrogels were characterized by gel fraction yield and degree of equilibrium swelling as well as by rheological measurements. The production of ethanol by immobilized Saccharomyces cerevisiae was used to test the suitability of the synthesized hybrid hydrogels to serve as carriers for cell immobilization. The presence of cells affected the mechanical properties and the structure of the polymer networks. The best system for immobilization was found to be the PEO/alginate/Ca, which exhibited high mechanical strength $\left(G^{\prime}, 830 ; \mathrm{GF}, 93 ; E S^{\mathrm{H}_{2} \mathrm{O}}, 15\right)$ without affecting the metabolic functions of the cells. The maximum ethanol yield was $0.42 \mathrm{~g} / \mathrm{g}$ corresponding to $82 \%$ of the theoretical yield.

Key words: hybrid networks; poly(ethylene oxide); alginate; chitosan; cell immobilization; ethanol production

\section{ИМОБИЛИЗАЦИЈА НА SACCHAROMYCES CEREVISIAE ВО НОВИ ХИДРОГЕЛОВИ НА БАЗА НА ХИБРИДНИ МРЕЖИ ОД ПОЛИ(ЕТИЛЕН ОКСИД), АЛГИНАТ И ХИТОЗАН ЗА ПРОДУКЦИЈА НА ЕТАНОЛ}

Матрици од хидрогелови врз база на хибридни мрежи од РЕО со природни полимери, алгинат или хитозан, беа добиени со UV вмрежување. Мрежите беа подготвени со еднократна постапка во која алгинатот или хитозанот беа додадени во растворот од РЕО за вмрежување, а со двократна постапка, проследена со дополнително хемиско вмрежување на алгинатот или хитозанот. Исто така беа подготвени двослојни хидрогелови составени од јадро од РЕО со заробени клетки и надворешен слој од природен хидрогел. Хидрогеловите беа карактеризирани со определување на гел-фракцијата, степенот на рамнотежно бабрење, како и со мерење на реолошките параметри. Тестирање на погодноста на синтетизираните хибридни хидрогелови како матрици за имобилизација на клетки за продукцијата на етанол беше направено со имобилизирани клетки од Saccharomyces cerevisiae. Присуството на клетките влијаеше врз механичките карактеристики и врз структурата на полимерните мрежи. Како најдобар систем за имобилизација беше селектиран $\mathrm{PEO}$ /alginate/Ca, кој покажа најголема механичка јачина $\left(G^{\prime}\right.$, $\left.830 ; \mathrm{GF}, 93 ; E S^{\mathrm{H}_{2} \mathrm{O}}, 15\right)$ без да влијае врз метаболичките функции на клетките. Максималниот принос на етанол беше $0,42 \mathrm{~g} / \mathrm{g}$, што одговара на 82 \% од теоретскиот принос.

Клучни зборови: хибридни мрежи; поли(етилен оксид); алгинат; хитозан; имобилизација на клетки; продукција на етанол 


\section{INTRODUCTION}

With the inevitable depletion of the world's energy supply, there has been an increasing worldwide interest in alternative sources of energy. Although biofuels offer diverse range of promising alternatives, ethanol constitutes $99 \%$ of all biofuels. Ethanol is a renewable, environmentally friendly fuel that is inherently cleaner than gasoline. Ethanol reduces harmful tailpipe emissions of carbon monoxide, particulate matters, oxides of nitrogen, and other ozone-forming pollutants $[1,2]$. Present world bioethanol production is around 50 billion litres per year and it is constantly expanding with a possibility to reach 120 billion litres per year until 2025 [3].

As the demand for ethanol has been growing, ethanol industry has to respond with improved, more efficient production technology and greater production capacity. This prospect includes fermentation with immobilized microorganisms. The use of immobilized yeast cell systems for alcoholic fermentation is rapidly expanding research area because of the technical and economical advantages compared with the free cell system. One method that has emerged as successful in the laboratory and promising in commercial applications is the entrapment of cells in polymer hydrogels [4]. Development of the hydrogels is a dynamic field of study wherein there is a continuous search for materials. Polymers are the largest group of materials being exploited. They are used separately and/or as compositions of natural and synthetic materials. Alginate and chitosan are two of the natural polymers with a numerous applications in the immobilization technology due to their non-toxic, biocompatible, biodegradable and antimicrobial properties $[5,6]$. Several groups have assessed the encapsulation of cells in double layer alginate or alginate-chitosan, microcapsules [7]. In some studies chitosan was used as the main matrix entrapping the cells [8]. In other studies chitosan or chitosan and alginate was used as the coating membrane of alginate microcapsules with entrapped cells $[9,10]$.

Recently, the effective syntheses of polymer hydrogels via UV irradiation were reported [11-13]. The advantages of the UV-crosslinking were the extremely short time for efficient gel formation and the simplicity of the technique. In our previous study, UV irradiated high molecular weight poly(ethylene oxide) (PEO) hydrogels with different crosslinkers were used for entrapment of Candida boidinii cells [11]. PEO was selected because of its properties: good strength, ability to increase the elasticity, non-toxicity and biocompatibility.

The objective of the present study was to develop novel hydrogels for cell immobilization based on UV irradiated high molecular weight PEO with natural polymers, alginate or chitosan in a single-stage procedure and in a two-stage procedure with additional chemical crosslinking. Double-layer hybrid hydrogels composed of PEO hydrogel core with entrapped cells and outer alginate or chitosan layer were also prepared. The polymer networks were characterized in terms of gel fraction yield, equilibrium swelling and rheological parameters, and tested for immobilization of Saccharomyces cerevisiae cells that were subsequently used for ethanol production.

\section{EXPERIMENTAL}

\section{1. Materials}

Saccharomyces cerevisiae, a commercial grade baker's yeast, with $32 \%$ dry biomass was used. Poly(ethylene oxide) was from Union Carbide Corp., USA Polyox N12K $\left(\bar{M}_{n}=1 \cdot 10^{6} \mathrm{~g} /\right.$ mol), sodium alginate with approximately $70 \%$ G-block content was from Aldrich, and chitosan (medium molecular weight, $\bar{M}_{n} \sim 4 \cdot 10^{5} \mathrm{~g} / \mathrm{mol}$ ) was from Fluka. The (4-benzoylbenzyl)trimethylammonium chloride (BBTMAC) purchased from Aldrich was used as a photoinitiator, without further purification. Other chemicals used were purchased from commercial sources and were of analytical grade.

\section{2. Preparation of hydrogels}

\section{2. 1. Single-stage procedure for hydrogels preparation}

Aqueous solution of PEO (5 mL, $5 \% \mathrm{w} / \mathrm{v})$ or PEO with $1 \% \mathrm{w} / \mathrm{v}$ sodium alginate or $1 \%$ 
$\mathrm{w} / \mathrm{v}$ chitosan containing BBTMAC $(5 \%$ of the polymer mass) was poured into a Teflon Petri dish with a diameter of $5 \mathrm{~cm}$, forming a $2 \mathrm{~mm}$ thick layer, which was then placed in a freezer at $-40{ }^{\circ} \mathrm{C}$ for 2 hours. The frozen solution was irradiated with UV light in a temperature-controlled open chamber connected with cryostat apparatus in a Dimax light curing system 5000-EC equipped with $400 \mathrm{~W}$ metal halide flood lamp (input power $\left.=93 \mathrm{~mW} / \mathrm{cm}^{2}\right)$, for 2 minutes $\left(\right.$ dose $\left.=11.4 \mathrm{~J} / \mathrm{cm}^{2}\right)$.

\section{2. 2. Two-stage procedure for hydrogels preparation}

$\mathrm{PEO} /$ alginate or $\mathrm{PEO} /$ chitosan hydrogels (prepared in single-stage procedure as above) were then additionally crosslinked with sterile solution of calcium chloride $(1 \mathrm{~mol} / \mathrm{L})$ to form $\mathrm{PEO} /$ alginate/Ca hydrogels or glutharaldehyde (GA) (3 $\% \mathrm{w} / \mathrm{v}$ ) for $\mathrm{PEO} /$ chitosan/GA hydrogels.

\section{2. 3. Double-layer hydrogels}

Aqueous solution of PEO (5 mL, $5 \% \mathrm{w} / \mathrm{v})$ containing BBTMAC (5\% of the polymer mass) was irradiated wih UV light. PEO hydrogels were then coated with solutions of sodium alginate (3 $\% \mathrm{w} / \mathrm{v})$ or chitosan $(3 \% \mathrm{w} / \mathrm{v})$. Finally, after 30 minutes reaction time, hydrogels were placed in solutions of calcium chloride $(1 \mathrm{~mol} / \mathrm{L})$ or glutharaldehyde $(3 \% \mathrm{w} / \mathrm{v})$, as crosslinking agents, to form outer layer.

\section{2. 4. Immobilization of the cells}

The yeast was immobilized by adding yeast cells $(5$ or $10 \% \mathrm{w} / \mathrm{v})$ to the mixture of polymers, followed by the same crosslinking procedure as already described. The size and shape of prepared hydrogels with yeast cells are as presented in Figure 1.

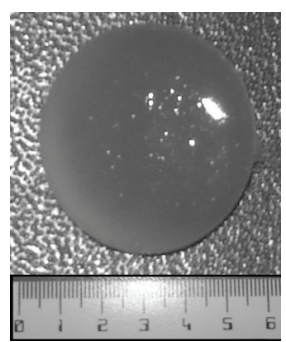

Fig. 1. PEO hydrogel disks loaded with yeast cells

\section{3. Characterization of the hydrogels}

\section{3. 1. Measurements of gel fraction yield and equilibrium degree of swelling}

For complete removal of sol fraction, the prepared hydrogels were soaked in water for 48 hours, and then they were taken out and dried to constant mass under vacuum and weighed. The gel fraction yield (GF) was calculated as:

Gel fraction $=\frac{\text { mass of the dried sample after extraction }}{\text { initial mass }} \cdot 100(\%)$

For determination of the equilibrium degree of swelling (ES), the hydrogels were equilibrated in distilled water or chloroform for at least $72 \mathrm{~h}$, removed from the solvent, blotted with filter paper and weighed. They were then dried to constant mass under vacuum and weighed again. The ES was calculated as:

Equilibrium swelling $=\frac{\text { mass of equilibrated swollen sample }}{\text { mass of dry sample }}$

\section{3. 2. Rheological measurements}

Dynamic rheological measurements of the hydrogels were performed on a Haake RheoStress 600 rheometer with a cone-plate system $\left(2^{\circ}\right)$ and Peltier temperature controller. Shear storage modulus $G^{\prime}$ and loss modulus $G^{\prime \prime}$ were measured in the frequency range of $0.1-10 \mathrm{~Hz}$ at $25^{\circ} \mathrm{C}$.

The experimental errors of the estimated $G F, E S, G^{\prime}$ and $G^{\prime \prime}$ values are $\pm 3 \%$.

\section{3. 3. Number average molecular weight between crosslinks}

The number average molecular weight between crosslinks, $\bar{M}_{c}$ was determined using the equilibrium swelling data and Flory and Rehner equation (Eq. 3) (for PEO) [14, 15] and the data for shear modulus $G^{\prime}$ (Eq. 4).

$$
\frac{1}{\bar{M}_{c}}=\frac{2}{\bar{M}_{n}}-\frac{\left(\bar{v} / V_{1}\right)\left[\ln \left(1-v_{2, s}\right)+v_{2, s}+\chi v_{2, s}^{2}\right]}{\left[\left(v_{2, s}\right)^{1 / 3}-\frac{v_{2, s}}{2}\right]}
$$

where $\bar{M}_{n}$ is the number average molecular weight of the polymer before crosslinking 
$\left(\bar{M}_{n}=1 \cdot 10^{6} \mathrm{~g} / \mathrm{mol}\right) ; \overline{\mathrm{v}}$ is the specific volume of the polymer (for PEO, $\rho=1.13 \mathrm{~g} / \mathrm{cm}$ and $\bar{v}$ $\left.=0.885 \mathrm{~cm}^{3} / \mathrm{g}\right) ; V_{1}$ is the molar volume of the swelling agent $\left(18 \mathrm{~cm}^{3} / \mathrm{mol}\right.$ for water; $80.67 \mathrm{~cm}^{3} /$ mol for chloroform); and $\chi$ is the Flory-Huggins constant (for PEO gels and water, 0.45; for PEO gels and chloroform 0.477) [14]. The polymer volume fraction in the equilibrium swollen polymer, $v_{2, s}$, was calculated as $v_{2 \mathrm{~s}}=1 / \mathrm{ES}$. mined as:

According to [16], $\bar{M}_{c}$ can be deter-

$$
\bar{M}_{c}=\frac{c R T}{G^{\prime}}
$$

where $R$ is the gas constant $(8.3143 \mathrm{~J} / \mathrm{mol} \mathrm{K}), T$ is the temperature $(298 \mathrm{~K})$ at which the modulus $G^{\prime}$ was measured, $c$ is polymer concentration $\left(5 \cdot 10^{4} \mathrm{~g} / \mathrm{m}^{3}\right)$ in the crosslinking solution.

\section{3. 4. Mesh size of the PEO polymer network}

The number of links between two crosslinks, $n$, was calculated as $n=\bar{M}_{c} / M_{\mathrm{r}}$, where $M_{\mathrm{r}}$ is the average molecular weight of the repeating unit. The mesh size of the polymer network, $\xi$, was calculated by [17]:

$$
\xi=v_{2, s}^{-1 / 3}\left(\frac{-2}{r_{0}}\right)^{1 / 2}
$$

where the root mean squared end-to-end distance of the polymer chain in the unperturbed state was calculated as $\left(\frac{-2}{r_{0}}\right)^{1 / 2}=\sqrt{C_{n}} \ell \sqrt{n} ; C_{\mathrm{n}}$ is the Flory characteristic ratio or rigidity factor of the polymer; $l$ is the carbon-carbon bond length, $n$ is the number of links along the polymer chain.

\section{3. 5. Scanning electron microscope}

Micrographs of cross-section and the interior of PEO hydrogel loaded with $S$. cerevisiae cells were obtained by using a Jeol JSM5510 scanning electron microscope (SEM). The composite hydrogels specimens were first dried, then quenched in liquid nitrogen, fixed on a glass substrate and coated with gold in a Jeol JFC-1200 fine coater for 60s.

\section{4. Cultivation of Saccharomyces cerevisiae}

The medium had the following composition (per litre): $10 \mathrm{~g}$ yeast extract, $2 \mathrm{~g} \mathrm{KH}_{2} \mathrm{PO}_{4}$, $1 \mathrm{~g} \mathrm{NaCl}, 0.2 \mathrm{~g} \mathrm{CaCl}_{2} \cdot 2 \mathrm{H}_{2} \mathrm{O}, 1.7 \mathrm{~g} \mathrm{MgSO}_{4} \cdot 7 \mathrm{H}_{2} \mathrm{O}$, $0.01 \mathrm{~g} \mathrm{FeCl}_{3} \cdot 6 \mathrm{H}_{2} \mathrm{O}, 2 \mathrm{~g} \mathrm{NH}_{4} \mathrm{Cl}$, and glucose. For preculturing the glucose concentration was $20 \mathrm{~g} / \mathrm{L}$ and for batch production of ethanol, it was increased to $50 \mathrm{~g} / \mathrm{L}$. The media were autoclaved at $121^{\circ} \mathrm{C}$ for $15 \mathrm{~min}$. The initial $\mathrm{pH}$ value was 5. Immobilized cells were cultivated in 50 $\mathrm{mL}$ nutrient medium placed in a $250 \mathrm{~mL}$ Erlenmeyer flask on a rotary shaker $(150 \mathrm{rpm})$ at 28 ${ }^{\circ} \mathrm{C}$. After 20 hours of precultivation, the immobilized cells were washed with sterile distilled water and transferred into the fresh nutrient medium for ethanol production. One gel of about 5 $\mathrm{mL}$ volume was placed in each flask providing $1: 10(\mathrm{v} / \mathrm{v})$ ratio of gel to medium.

\section{5. Analytical methods}

Cell concentration was estimated by UVVIS spectrometer (Varian) at $620 \mathrm{~nm}$, after diluting the samples within the range of 0.05 to 0.5 units. One optical density unit corresponded to $0.3 \mathrm{mg}$ dry cell mass per mL. Samples were clarified by centrifugation (Heraus) at $2500 \times g$ for $15 \mathrm{~min}$ for products and residual sugar analysis. Supernatants were stored at $-18{ }^{\circ} \mathrm{C}$ before analysis. Ethanol was analyzed by gas chromatography using a Varian CP 3800 with a capillary column WCOT fused silica $(30 \mathrm{~m} \times$ $0.32 \mathrm{~mm}$ ), CP WAX $52 \mathrm{CB}, d_{f}=0.25 \mu \mathrm{m}$ and a manual injector type 1709 . The injector and detector temperatures were $250{ }^{\circ} \mathrm{C}$, and the column temperature was $200^{\circ} \mathrm{C}$. Nitrogen was used as a carrier gas with a flow rate of $30 \mathrm{~mL} /$ min. Isopropanol was used as an internal standard. Glucose concentration was determined by a 3,5-dinitrosalicylic acid procedure of Miller. The mean of two individual measurements was used to calculate the glucose, ethanol and cell concentration. 


\section{RESULTS AND DISCUSSION}

\section{1. Physical and mechanical properties of hydrogels}

Hydrogel matrices were designed as hybrid networks of PEO and natural polymers, alginate or chitosan, by UV irradiation, with additional chemical crosslinking. Double-layer hydrogels composed of PEO hydrogel core with entrapped cells and outer natural hydrogel layer were also synthesized. The properties of the formed hydrogels, as shown in Figure 2, were affected by the hydrogel preparation technique. Gel fraction yields between 53 and $93 \%$ and equilibrium degrees of swelling between 5 and 65 in chloroform were determined. Two-stage preparation procedure contributed to the higher values of gel fraction yield, $93 \%$ for $\mathrm{PEO} / \mathrm{al}$ ginate/Ca and $87 \%$ for $\mathrm{PEO} /$ chitosan/GA, and to the smaller equilibrium degree of swelling, $E S^{\mathrm{CHCl}_{3}=11}$ for $\mathrm{PEO} /$ alginate/Ca, and $E S^{\mathrm{CHCl}_{3}=5}$ for $\mathrm{PEO} /$ chitosan/GA, respectively. As expected, additional crosslinking of natural polymers resulted in the networks that allow less swelling. The phenomena of adding a crosslinking agent to decrease water uptake has also been noted by other authors [18].

The physico-mechanical properties of the hydrogels are of crucial importance. The presence of cells during the preparation of the matrices can affect the physical properties and the structure of the formed polymeric matrix. Therefore, all

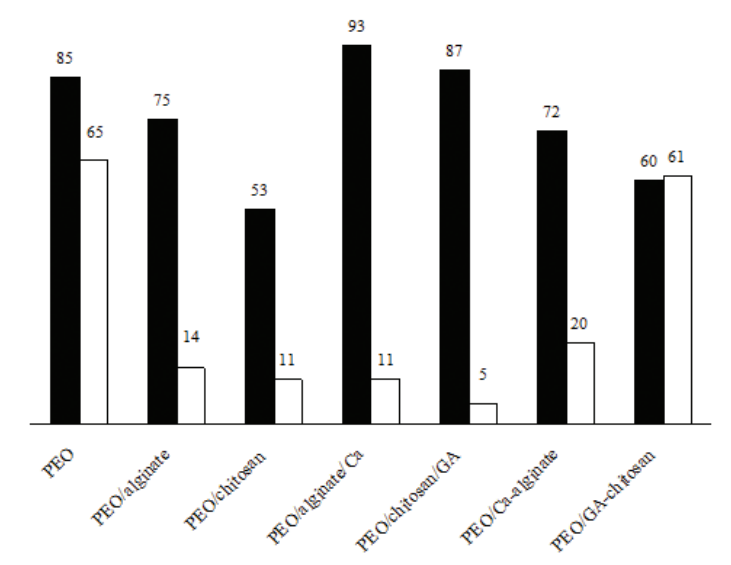

Fig. 2. Hydrogels prepared by UV irradiation. Gel fraction yield (\%) (匹), equilibrium swelling degree in chloroform ( $\square$ ).

studies were performed on hydrogels without and with incorporated yeast cells and the results are presented in Figure 3. The apparent values of $G^{\prime}$ and $G^{\prime \prime}$ were independent of the frequency and $G^{\prime}>G^{\prime \prime}$ over the entire frequency range explored. The observed results were consistent with the typical behaviour of a polymer gel. For the control sample of PEO hydrogels, irradiated at room temperature, the values of $G^{\prime}$ and $G^{\prime \prime}$ were $255 \mathrm{~Pa}$ and $10 \mathrm{~Pa}$. The hybrid hydrogels exhibited quite a different behaviour. The values of $G^{\prime}$, as shown in Figure 3a, are orders of magnitude higher than the values for the PEO hydrogels. The highest increase of $G^{\prime}$ was observed with $\mathrm{PEO} /$ alginate/Ca (3.3-fold) and PEO/chitosan/GA (2.8fold) as compared to the control sample of PEO hydrogels. Our study evidently showed that the two-stage procedure for hydrogel preparations resulted in strong and stable matrices.
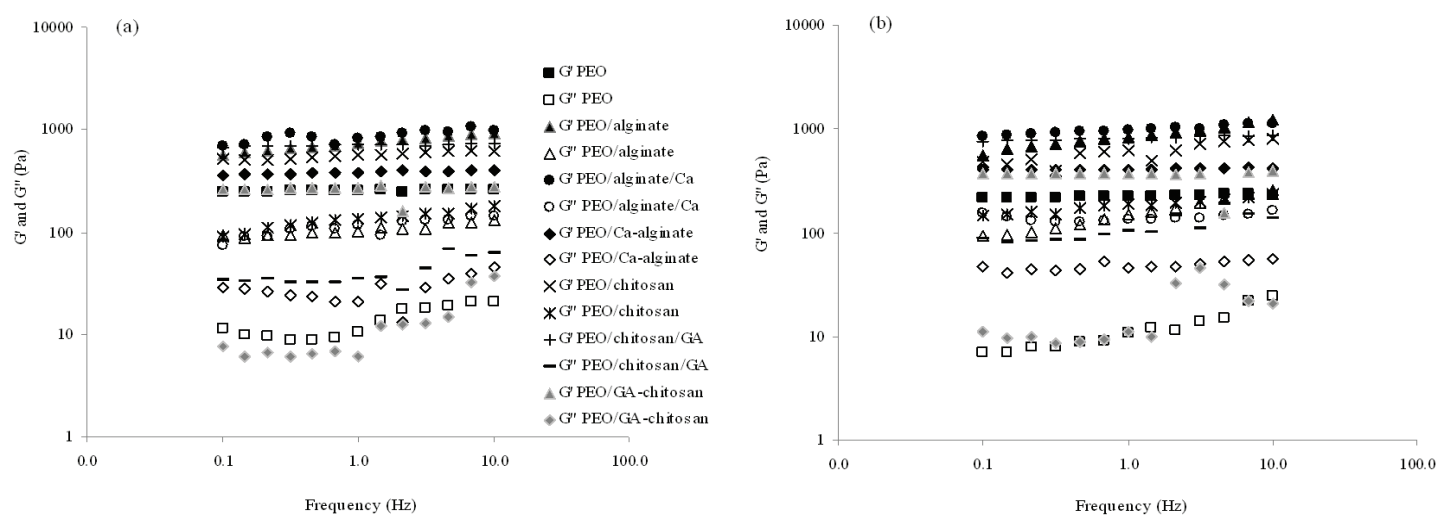

Fig. 3. Mechanical spectra of differently prepared PEO based hydrogels. Elastic modulus $\left(G^{\prime}\right)$ and loss modulus ( $\left.G^{\prime \prime}\right)$ of hydrogels without cells (a) and loaded with cells (b) 
Several authors reported on a decrease in the mechanical properties of the gel matrices as a result of the presence of microbial cells [11, 1921]. Our findings in these experiments indicated that the incorporation of the yeast cells had an impact on the viscoelastic properties of all gels studied and the resultant hydrogel networks were of high mechanical strength, causing increase of $G^{\prime}$ values (Figure $3 b$ ). $\mathrm{PEO} /$ alginate/Ca and $\mathrm{PEO} /$ chitosan/GA with entrapped cells, exhibited the highest values of storage modulus, 977 and 812 $\mathrm{Pa}$, respectively, recorded at $1 \mathrm{~Hz}$, compared with $830 \mathrm{~Pa}$ and $710 \mathrm{~Pa}$ for the same hydrogels without cells. When cells were incorporated in the polymer networks a decrease of $G^{\prime}$ values was observed only with the control sample of PEO hydrogel (225 Pa).

The approximate values of the number average molecular weights between crosslinks, $\bar{M}_{c}$, was calculated for PEO networks, thus characterizing the extent of crosslinking.
The results for $\bar{M}_{c}$ and mesh size, derived from two experimental methods including swelling (in water and chloroform) and dynamic mechanical analysis for PEO hydrogel are presented in Table 1. It can be noted that value for $\bar{M}_{c}$ calculated according to Eq. 3 for swelling in chloroform $(434,000 \mathrm{~g} / \mathrm{mol})$ were comparable with the value for $\bar{M}_{c}$ calculated from dynamic rheological measurements $(486,000 \mathrm{~g} / \mathrm{mol})$, since chloroform is a better swelling agent for this type of hydrogel. The equivalent mesh sizes were similar as well, 173 and $161 \mathrm{~nm}$, respectively. Scanning electron microscopy revealed the presence of $S$. cerevisiae in the inner region of PEO hydrogel loaded with cells. In Figure 4 the relative size of both cells and matrix porosity are seen. The size of the pores gives enough space for the growth of gel-entrapped cells. Morphology of $S$. cerevisiae cells does not seem to be affected by the UV-crosslinking entrapment procedure.
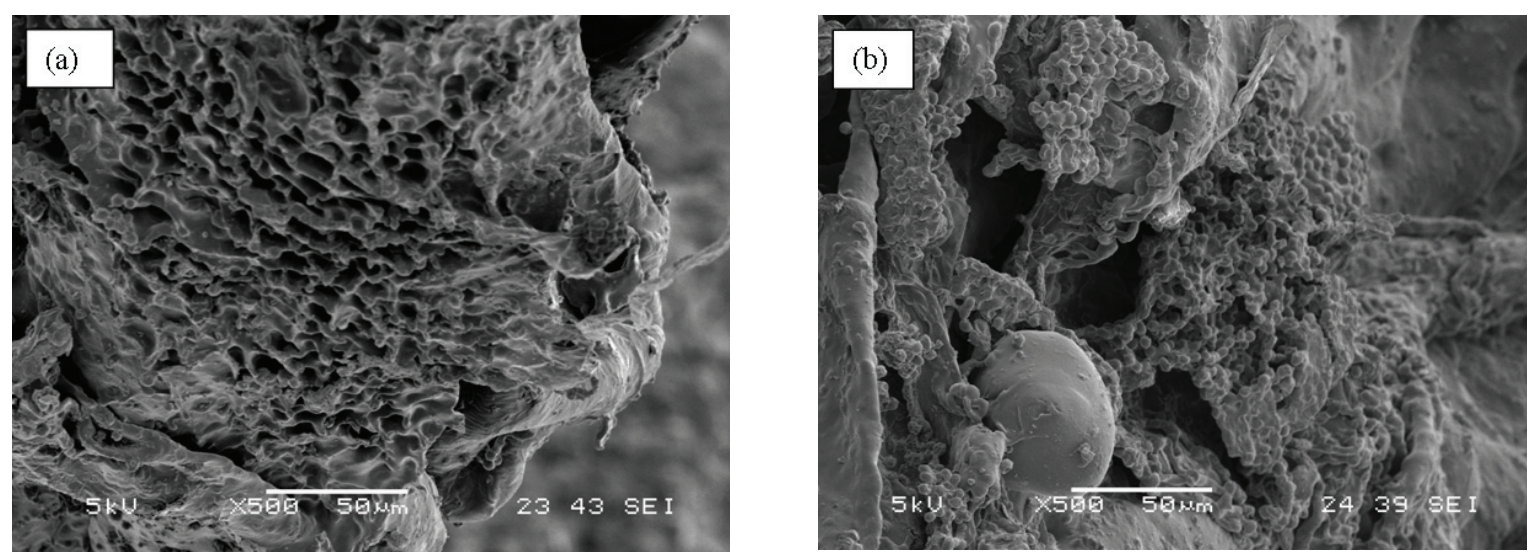

Fig. 4. Scanning electron micrographs (SEM) of the cross-section of PEO hydrogel loaded with $S$. cerevisiae cells after immobilization (a) and after one fermentation cycle of 24 hours (b)

Table 1

Number average molecular weight between crosslinks and mesh size for PEO hydrogels

\begin{tabular}{|c|c|c|c|c|c|c|c|c|c|}
\hline & $E S^{H_{2} \mathrm{O}}$ & $\begin{array}{c}\bar{M}_{c}^{\mathrm{a}} \\
(\mathrm{g} / \mathrm{mol})\end{array}$ & $\begin{array}{c}\xi \\
(\mathrm{nm})\end{array}$ & $E S^{C H C L_{3}}$ & $\begin{array}{c}\bar{M}_{c}^{\mathrm{b}} \\
(\mathrm{g} / \mathrm{mol})\end{array}$ & $\begin{array}{c}\xi \\
(\mathrm{nm})\end{array}$ & $\begin{array}{c}G^{\prime} \\
(\mathrm{Pa})\end{array}$ & $\begin{array}{c}\bar{M}_{c}^{\mathrm{c}} \\
(\mathrm{g} / \mathrm{mol})\end{array}$ & $\begin{array}{c}\xi \\
(\mathrm{nm})\end{array}$ \\
\hline PEO & 44 & 135,000 & 85 & 65 & 434,000 & 173 & 255 & 486,000 & 161 \\
\hline
\end{tabular}

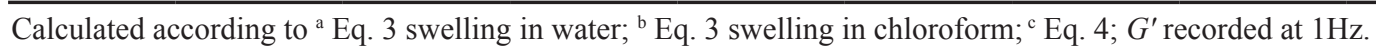


The apparent values for $\bar{M}_{c}$ for the hybrid hydrogels, calculated by dynamic rheological measurements, are summarized in Table 2. It can be seen that increasing the crosslinking

Table 2 density resulted in an increase of $G^{\prime}$, and consequently a decrease of $\bar{M}_{c}$ values. The values for $\bar{M}_{c}$ varied from 149,000 to $221,000 \mathrm{~g} / \mathrm{mol}$.

Number average molecular weight between crosslinks for hybrid networks based on PEO.

\begin{tabular}{lccc}
\hline System & $\begin{array}{c}\text { Concentration of } \\
\text { polymer (w/w \%) }\end{array}$ & $\begin{array}{c}G^{\prime} \\
(\mathrm{Pa})\end{array}$ & $\begin{array}{c}\bar{M}_{c} * \\
(\mathrm{~g} / \mathrm{mol})\end{array}$ \\
\hline $\mathrm{PEO} /$ alginate & $5 / 1$ & 725 & 171,000 \\
$\mathrm{PEO} /$ chitosan & $5 / 1$ & 562 & 221,000 \\
$\mathrm{PEO} /$ alginate/Ca & $5 / 1$ & 830 & 149,000 \\
$\mathrm{PEO} /$ chitosan/GA & $5 / 1$ & 710 & 174,000 \\
\hline \hline
\end{tabular}

${ }^{*}$ Calculated according to Eq. 4 ; $G^{\prime}$ recorded at $1 \mathrm{~Hz}$.

\section{2. Activity of the immobilized yeast cells}

\section{2. 1. Effect of the initial yeast cell loading on the fermentation behaviour of the yeast}

The effect of the initial cell loading in hydrogels on cell proliferation, metabolic activity and product formation by the immobilized cells was investigated. It has been generally observed that it is difficult to predict the type and magnitude of the metabolic changes in the cells due to the immobilization procedure. The first experment

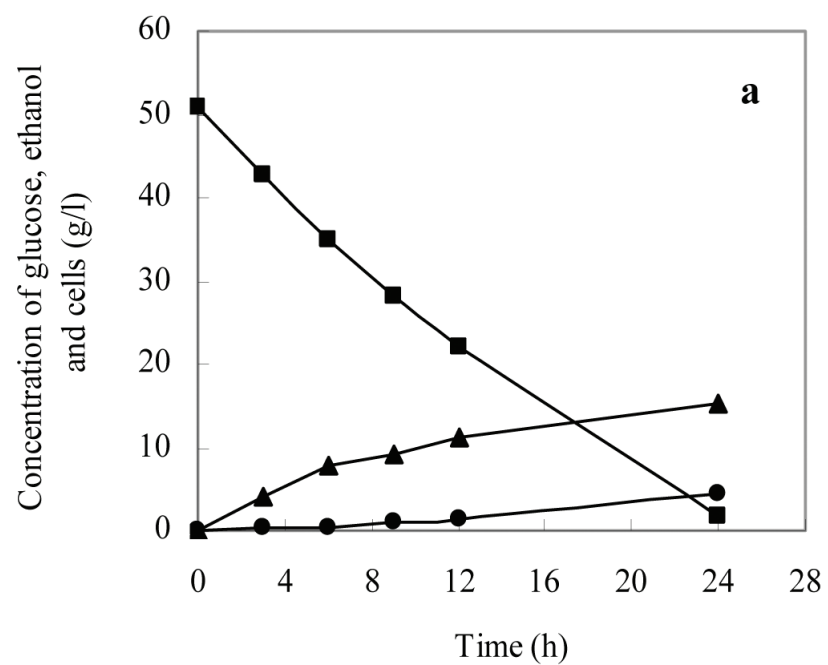

with PEO immobilized $S$. cerevisiae cells demonstrated that immobilization procedure did not affect cell activity. Figure 5 showed the distinctive profile of glucose consumption and ethanol formation in immobilized cell culture with different initial cell loadings of 5 and $10 \% \mathrm{w} / \mathrm{v}$. It was clear that both culture systems had a good metabolic activity. The ethanol production started at $3^{\text {rd }}$ hour, and reached a maximum level at $24^{\text {th }}$ hour $(15.3 \mathrm{~g} / \mathrm{L})$ with $5 \%$ entrapped cells (Figure $5 \mathrm{a}$ ), while with $10 \%$ entrapped cells (Figure $5 \mathrm{~b}$ ) ethanol concentration reached its maximum level $(14.7 \mathrm{~g} / \mathrm{L})$ at $12^{\text {th }}$ hours.

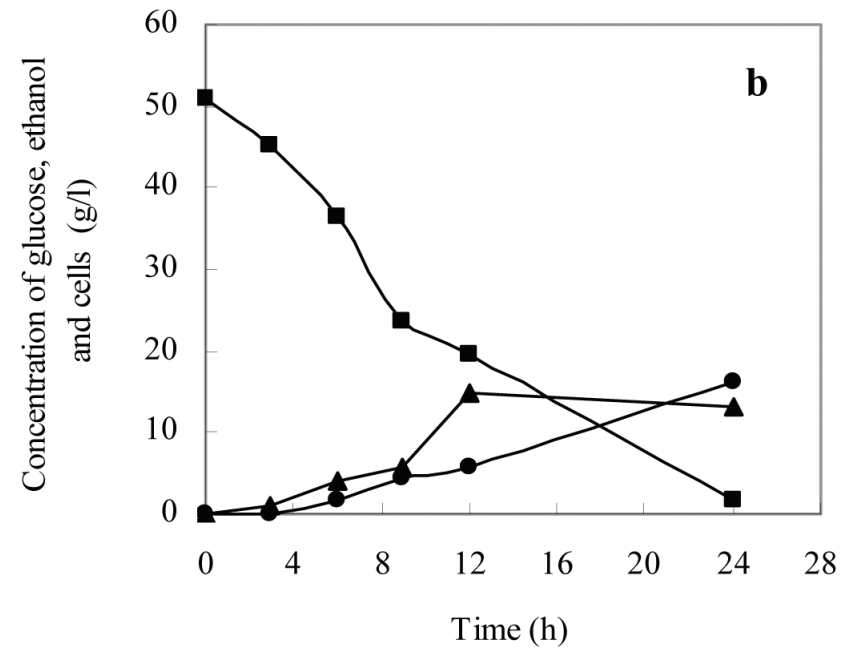

Fig. 5. Glucose $(\boldsymbol{\bullet})$, ethanol $(\boldsymbol{\Delta})$, and biomass $(\bullet)$ concentration during batch culture of immobilized S. cerevisiae in synthetic PEO hydrogel with cell loading (a) $5 \% \mathrm{w} / \mathrm{v}$ and (b) $10 \% \mathrm{w} / \mathrm{v}$ 
However, the concentration of the free cells in the medium was very high, $16.04 \mathrm{~g} / \mathrm{L}$ at $24^{\text {th }}$ hour in the case with $10 \%$ entrapped cells, thus suggesting that the cell load of $5 \% \mathrm{w} / \mathrm{v}$ was a better choice for further immobilization studies. Lower initial cell density in microcapsules of alginate-chitosan-alginate was also reported to be better for proliferation, metabolism and product formation by S. cerevisiae [9].

One of the most common problem to overcome in using entrapped yeast cells for fermentation is the leakage of cells from the entrapment matrix into the medium. In the next experiments, our ultimate goal was to create hydrogel/cell systems where the core PEO
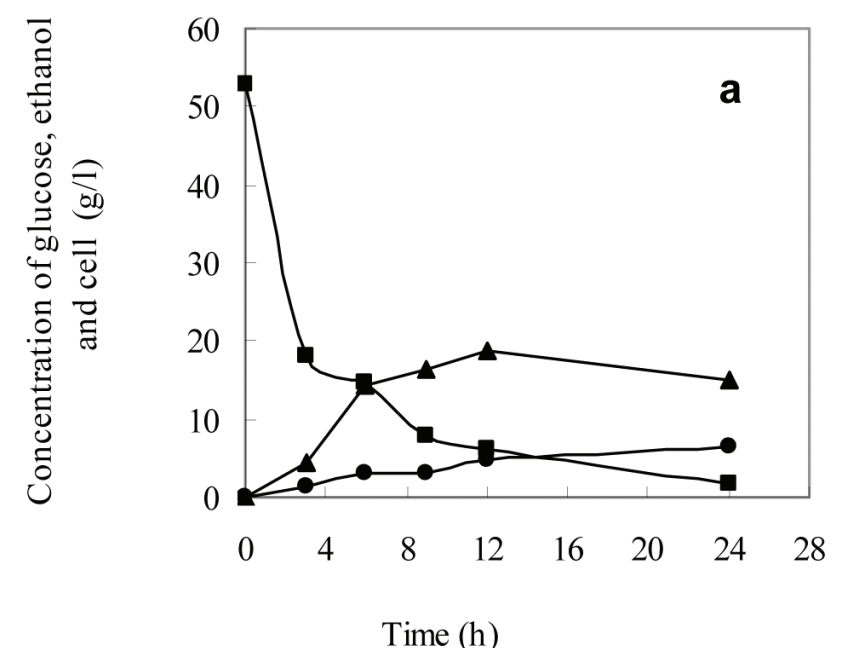

hydrogel will contain the immobilized cells and the additional polymer will ensure the mechanical strength and will act as barrier membrane against cell leakage as well. For this purpose, yeast cells were cultivated in the hybrid hydrogels and double-layer carriers based on PEO hydrogels with natural polymers, alginate or chitosan. The size of the hydrogel samples and yeast cell content $(5 \% \mathrm{w} / \mathrm{v})$ were prepared to be identical for the three techniques of preparation. The effects of these types of polymer matrices on the ethanol production by immobilized $S$. cerevisiae are demonstrated in Figures 6 and 7.
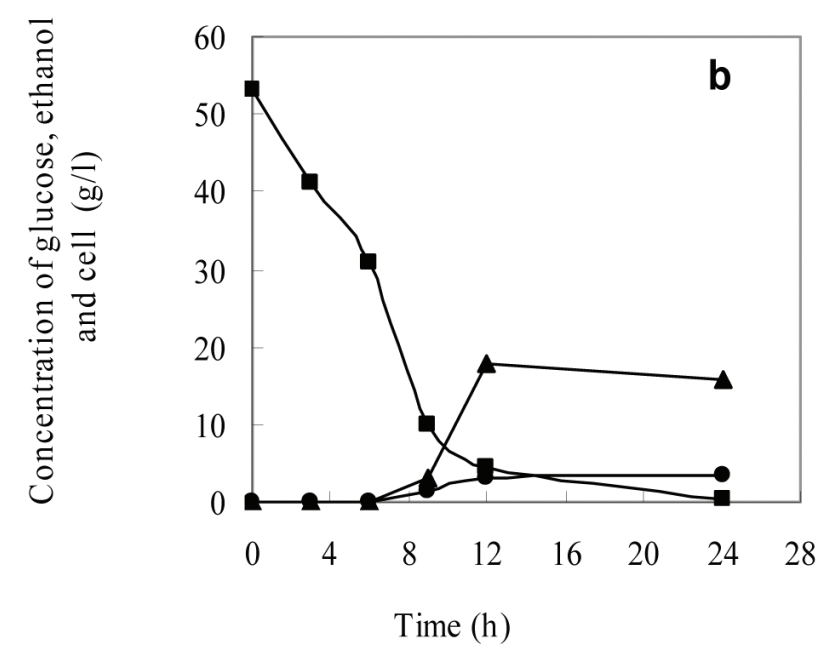

Fig. 6. Time course of glucose $(\boldsymbol{\bullet})$, ethanol $(\boldsymbol{\Delta})$ and cell mass $(\bullet)$ concentration in batch cultivation with entrapped $S$. cerevisiae cells carriers with alginate: (a) PEO/alginate and (b) PEO/alginate/Ca
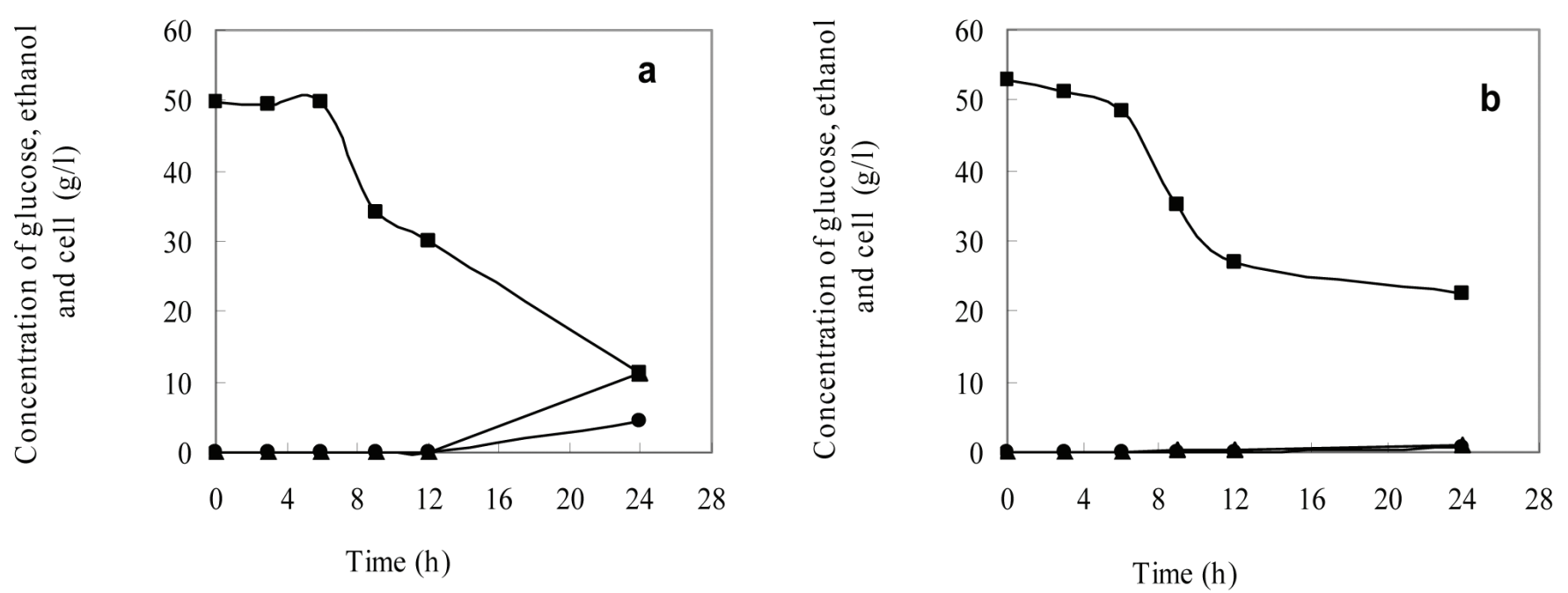

Fig. 7. Time course of glucose $(\boldsymbol{\square})$, ethanol $(\boldsymbol{\Delta})$ and cell mass $(\boldsymbol{O})$ concentration in batch cultivation with entrapped $S$. cerevisiae cells carriers with chitosan: (a) PEO/chitosan and (b) PEO/chitosan/GA. 


\section{2. 2. Ethanol production by immobilized cells in PEO-based hybrid hydrogels}

The behaviour of the immobilized Saccharomyces cerevisiae in $\mathrm{PEO} /$ alginate and $\mathrm{PEO} /$ alginate/Ca hybrid hydrogels is presented in Figure 6. The rapid glucose consumption in the first $12 \mathrm{~h}$ of the fermentation coincided with the maximum ethanol production of 18.6 $\mathrm{g} / \mathrm{L}$ (78\% from the theoretical yield) for the $\mathrm{PEO} /$ alginate and $19.0 \mathrm{~g} / \mathrm{L}$ ethanol ( $82 \%$ from the theoretical yield) for the $\mathrm{PEO} /$ alginate/Ca. These results suggested that both $\mathrm{PEO} /$ alginate and $\mathrm{PEO} /$ alginate/Ca could serve as matrices for yeast cell immobilization and could be used for ethanol production. However, the cell leakage in the medium with $\mathrm{PEO} /$ alginate $(4.9 \mathrm{~g} / \mathrm{L})$ was higher than the cell leakage with $\mathrm{PEO} / \mathrm{al}-$ ginate/Ca (3.0 g/L). Obviously, the PEO/alginate could not retain the proliferated cells due to its lower crosslinking density (GF, $75 \%$ and $E S^{\mathrm{H}_{2} \mathrm{O}}, 33$ ) compared to $\mathrm{PEO} /$ alginate/Ca (GF, 93 and $\left.E S^{\mathrm{H}_{2} \mathrm{O}}, 15\right)$. These results suggested that the $\mathrm{PEO} /$ alginate/Ca could be used as a yeast cell carrier for ethanol production in scaled-up experiments. These experiments should employ higher initial glucose concentration and should be carried out for a longer time so that the operational stability of the system could be also investigated.

In the fermentation with entrapped cells in $\mathrm{PEO} /$ chitosan and $\mathrm{PEO} /$ chitosan/GA, the cells did not start consuming glucose before $6^{\text {th }}$ hour (Figure 7). The cells might be inactivated not only due to the immobilization procedure, but also due to the composition of the hydrogels. Additionally, ethanol was not detected before $24^{\text {th }}$ hour. It was assumed that ethanol was produced only by $S$. cerevisiae cells immobilized in PEO/chitosan $(11.1 \mathrm{~g} / \mathrm{L})$ due to the more expressed swelling in water media $\left(E S^{\mathrm{H}_{2} \mathrm{O}}=19\right)$ compared to $\mathrm{PEO} /$ chitosan/GA $\left(E S^{\mathrm{H}_{2} \mathrm{O}=9}\right)$. In addition, the absence of the ethanol in the $\mathrm{PEO} /$ chitosan/GA was most probably a result of the use of glutharaldehyde as a crosslinker. Similar behaviour of the immobilized cells has been also reported [22]. Because of the toxic effect of the glutharaldehyde, on the one hand, and the solid physico-mechanical properties of the $\mathrm{PEO} /$ chitosan/GA, on the other hand, a substitution of glutharaldehyde by sodium tripolyphosphate will be investigated as alternative.

\subsubsection{Ethanol production by immobilized cells in PEO-based double-layer hydrogels}

Immobilized $S$. cerevisiae cells in doublelayer hydrogels of $\mathrm{PEO} / \mathrm{Ca}$-alginate and $\mathrm{PEO} / \mathrm{GA}$ chitosan did not produce ethanol (data not shown). Besides, the double-layer polymer carriers did not fulfil our expectations of good mechanical properties. The outer layer of these carriers was fragile. As shown in Figure $3 \mathrm{~b}$, the $G^{\prime}$ values were the lowest of all hybrid hydrogels, $404 \mathrm{~Pa}$ for $\mathrm{PEO} / \mathrm{Ca}$-alginate and $376 \mathrm{~Pa}$ for PEO/GA-chitosan.

\section{CONCLUSIONS}

Hydrogel matrices were designed as hybrid networks of poly(ethylene oxide) with natural polymers, alginate or chitosan, by UV irradiation and chemical crosslinking. We explored the feasibility of these hybrid hydrogels as matrices for immobilization of Saccharomyces cerevisiae cells. The immobilized yeast cells were used for ethanol production from glucose. The best system for immobilization was found to be PEO/alginate/ $\mathrm{Ca}$, which exhibited high mechanical strength and did not negatively affect the metabolic activity of the cells. In addition, the PEO/alginate/Ca system reduced significantly the leakage of the entrapped cells into the medium. Having selected the proper carrier, the further experiments should focus on optimizing the conditions for ethanol production.

Acknowledgments: The authors acknowledge the financial support of the Macedonian Ministry of Education and Science, and the Institute of Polymers at the Bulgarian Academy of Sciences. 


\section{NOMENCLATURE}

\begin{tabular}{|c|c|}
\hline BВТМAC & $\begin{array}{l}\text { (4-benzoylbenzyl)trimethylammonium } \\
\text { chloride }\end{array}$ \\
\hline$E S$ & equilibrium swelling degree \\
\hline $\mathrm{ES}^{\mathrm{CHCl}_{3}}$ & equilibrium swelling degree in chloroform \\
\hline$E S^{H_{2} \mathrm{O}}$ & equilibrium swelling degree in water \\
\hline$G^{\prime}$ & elastic modulus, $\mathrm{Pa}$ \\
\hline$G^{\prime \prime}$ & loss modulus, $\mathrm{Pa}$ \\
\hline GA & glutharaldehyde \\
\hline GF & gel fraction yield, $\%$ \\
\hline PEO & poly(ethylene oxide) \\
\hline $\mathrm{PEO}$ /alginate & $\begin{array}{l}\text { hybrid network of poly(ethylene oxide) } \\
\text { and sodium alginate }\end{array}$ \\
\hline $\mathrm{PEO} /$ alginate/Ca & $\begin{array}{l}\text { hybrid network of poly(ethylene oxide) } \\
\text { and calcium alginate }\end{array}$ \\
\hline $\mathrm{PEO} / \mathrm{Ca}$-alginate & $\begin{array}{l}\text { double-layer carrier of poly(ethylene oxide) } \\
\text { and calcium alginate }\end{array}$ \\
\hline $\mathrm{PEO} /$ chitosan & $\begin{array}{l}\text { hybrid network of poly(ethylene oxide) } \\
\text { and sodium alginate }\end{array}$ \\
\hline $\mathrm{PEO} /$ chitosan/GA & $\begin{array}{l}\text { hybrid network of poly(ethylene oxide) } \\
\text { and chitosan-glutharaldehyde }\end{array}$ \\
\hline PEO/GA-chitosan & $\begin{array}{l}\text { double-layer carrier of poly(ethylene oxide) } \\
\text { and glutharaldehyde-chitosan }\end{array}$ \\
\hline SEM & scanning electron microscope \\
\hline
\end{tabular}

\section{REFERENCES}

[1] Y. Lin, S. Tanaka, Ethanol fermentation from biomass resources: Current state and prospects, Appl. Microbiol. Biotechnol., 69, 627-642 (2006).

[2] A. J. Ragauskas, C. K. Williams, B. H. Davison, G. Britovsek, J. Cairney, C. A. Eckert, W. J. Frecerick Jr., J. P. Hallett, D. J. Leak, C. L. Liotta, J. R. Mielenz, R. Murphy, R. Templer, T. Tschaplinski, The path forward for biofuels and biomaterials, Science, 311, 484-489 (2006).

[3] F. O. Licht, World ethanol production 2007 to hit new record, World Ethanol and Biofuels Report, 5, at http://www.agra-net.com/portal2/. Accessed 22.01.2010.

[4] V. I. Lozinsky, Polymeric cryogels as a new family of macroporous and supermacroporous materials for biotechnological purposes, Russ. Chem. Bull., Int. Ed., 57, (5) 1015-1032 (2008).

[5] O. Smidsrød, G. Skjåk-Bræk, Alginate as immobilisation matrix for cells, Tibtech, 8, 71-78 (1990).

[6] K. V. Harish Prashanth, R. N. Tharanthan, Chitin/ chitosan: modifications and their unlimited application potential - an overview, Trends Food Sci. Tech., 18, 117-131 (2007).

[7] M. Liouni, P. Drichoutis, E.T. Nerantiz, Studies of the mechanical properties and the fermenta- tion behaviour of double-layer alginate-chitosan beads, using Saccharomyces cerevisiae entrapped cells, World J. Microbiol. Biotechnol., 24, 281-288 (2008).

[8] H. Y. Kawaguti, E. M. Celestino, A. L. L. Moraes, D. K. Yim, L. K. Yamamoto, H. H. Sato, Characterization of a glucosyltransferase from Erwinia sp. D12 and the conversion of sucrose into isomaltulose by immobilised cells, Biochem. Eng. J., 48, 211-217 (2010).

[9] Q. Wen-tao, Y. Wei-ting, X. Yu-bing, M. Xiaojun, Optimization of Saccharomyces cerevisiae culture in alginate-chitosan-alginate microcapsule, Biochem. Eng. J., 25, 151-157 (2005).

[10] A. Bartowiak, S. Lisiecki, G. Orive, J. L. Pedraz, The effect of selected parameters of formation on properties of alginate $/ \mathrm{Ca}^{2+} /$ ligochitosan capsules, J. Chem. Tech. Biotech., 81, 511-518 (2006).

[11] E. Winkelhausen, R. Jovanović-Malinovska, S. Kuzmanova, M. Cvetkovska, Ch. Tsvetanov, Hydrogels based on u.v.-crosslinked poly(ethylene oxide) - matrices for immobilisation of Candida boidinii cells for xylitol production, World $J$ Microbiol., Biotechnol. 10, (24) 2035-2043 (2008).

[12] E. Veličkova, E. Winkelhausen, S. Kuzmanova, M. Cvetkovska, Ch. Tsvetanov, Hydroxyethylcellulose cryogels used for entrapment of Saccharomyces cerevisiae cells, React. Funct. Polym., 69, 688-693 (2009).

[13] P. Petrov, E. Petrova, Ch. B. Tsvetanov, UV-assisted synthesis of super-macroporous polymer hydrogels, Polymer 20, 1118-1123 (2009).

[14] M. Doytcheva, D. Dotcheva, R. Stamenova, A. Orahovats, Ch. Tsvetanov, J. Leder, Ultraviolet-induced crosslinking of solid poly(ethylene oxide), J. Appl. Polym., Sci. 64, 2297-2307 (1997).

[15] S. H. Emami, R. Salovey, Crosslinked poly (ethylene oxide) hydrogels, J. Appl. Polymer Sci., 88, 1451-1455 (2003).

[16] P. Eiselt, K. Y. Lee, D. J. Mooney, Rigidity of twocomponent hydrogels prepared from alginate and poly(ethylene glycol)-diamines. Macromolecules, 32, 5561-5566 (1999).

[17] J. L. Stringer, N. A. Peppas, Diffusion of small molecular weight drugs in radiation-crosslinked poly(ethylene oxide) hydrogels. J. Control Release., 42, 195-202 (1996).

[18] M. B. Mellott, K. Searcy, M. V. Pishko, Release of protein from highly cross-linked hydrogels of poly(ethylene glycol) diacrylate fabricated by UV polymerization, Biomaterials, 22, 929-941 (2001). 
[19] V. I. Lozinsky, A. L. Zubov, E. F. Titova, Poly(vinyl alcohol) cryogels employed as matrices for cell immobilisation. 2. Entrapped cells resemble porous fillers in their effects on the properties of PVA-cryogel carrier, Enz. Microb. Technol., 20, (3) 182-190 (1997).

[20] V. Manojlovic, J. Djonlagić, B. Obradović, V. Nedović, B. Bugarski, Investigation of cell immobilization in alginate: rheological and electrostatic extrusion studies. J. Chem. Tech. Biotech., 81, 505-510 (2006).
[21] T. S. Khaw, Y. Katakura, K. Ninomiya, C. Moukamnerd, A. Kondo, M. Ueda, S. Shioya, Enhancement of ethanol production by promoting surface contact between starch granules and arming yeast in direct ethanol fermentation, J. Biosci. Bioeng., 103 (1) 95-97 (2007).

[22] J. Berger, M. Reist, J. M. Mayer, O. Felt, N. A. Peppas, R. Gurny, Structure and interactions in covalently and ionically crosslinked chitosan hydrogels for biomedical applications, Eur. J. Pharm. Biopharm., 57, 19-34 (2004). 